Review

\title{
Novel Insights into the Immunomodulatory Effects of Caryophyllane Sesquiterpenes: A Systematic Review of Preclinical Studies
}

\author{
Marco Gulli ${ }^{\dagger}$, Ester Percaccio ${ }^{\dagger}$, Silvia Di Giacomo (D) and Antonella Di Sotto *(D)
}

Citation: Gullì, M.; Percaccio, E.; Di Giacomo, S.; Di Sotto, A. Novel Insights into the Immunomodulatory Effects of Caryophyllane Sesquiterpenes: A Systematic Review of Preclinical Studies. Appl. Sci. 2022, 12, 2292. https://doi.org/10.3390/ app12052292

Academic Editor: Owen Kavanagh

Received: 30 December 2021

Accepted: 21 February 2022

Published: 22 February 2022

Publisher's Note: MDPI stays neutral with regard to jurisdictional claims in published maps and institutional affiliations.

Copyright: (C) 2022 by the authors. Licensee MDPI, Basel, Switzerland. This article is an open access article distributed under the terms and conditions of the Creative Commons Attribution (CC BY) license (https:// creativecommons.org/licenses/by/ $4.0 /)$.
Department of Physiology and Pharmacology "V. Erspamer", Sapienza University, Piazzale Aldo Moro 5, 00185 Rome, Italy; marco.gulli@uniroma1.it (M.G.); ester.percaccio@uniroma1.it (E.P.); silvia.digiacomo@uniroma1.it (S.D.G.)

* Correspondence: antonella.disotto@uniroma1.it

+ These authors contributed equally to this work.

\begin{abstract}
Immunomodulation is a key factor in the homeostasis of organisms, both for physiological and inflammatory conditions. In this context, great attention has been devoted to immunomodulant agents, which can boost or modulate the immune system, thus favoring disease relief. The present systematic review is focused on the immunomodulatory properties of plant-based caryophyllane sesquiterpenes, which are unique natural compounds widely studied due to their multiple and pleiotropic bioactivities. Despite lacking clinical evidence, the selected studies highlighted the ability of these substances, especially $\beta$-caryophyllene and $\alpha$-humulene, to modulate the immune system of both in vitro and in vivo models of disease, such as neurodegenerative and inflammatorybased diseases, cancer, and allergies; moreover, some mechanistic hypotheses have been made too. The present overview suggests a further interest in immunomodulation by caryophyllane sesquiterpenes as a possible novel strategy for immune-based diseases or as an adjuvant treatment and encourages further high-quality studies, using high-purity compounds, to better clarify the mechanisms accounting for these properties and to support a further pharmaceutical development.
\end{abstract}

Keywords: immune system; immunomodulation; inflammation; $\beta$-caryophyllene; $\beta$-caryophyllene oxide; microglia; $\alpha$-humulene; sesquiterpenes; macrophages; lymphocytes; immune cells

\section{Introduction}

Caryophyllane sesquiterpenes are natural substances widely occurring in marine species, fungi, and especially in plants, where mixtures of $\beta$-caryophyllene, $\beta$-caryophyllene oxide, $\alpha$-humulene, and isocaryophyllene with minor metabolites are usually found [1]. Essential oils from Eugenia caryophyllata L. (syn. Syzygium aromaticum (L.) Merr.), Hypericum perforatum L., Mentha suaveolens L., and Cannabis sativa L., along with herbal extracts from Piper nigrum L. and Harpagophytum procumbens DC are only some examples of the natural sources of these compounds [1-6]. Over the years, great attention has been devoted to their bioactivities, with $\beta$-caryophyllene being especially studied due to its analgesic, anti-inflammatory, antioxidant, neuroprotective, antidiabetic, and chemopreventive properties; moreover, its ability to modulate cannabinoid CB2 receptors has been highlighted too [1]. However, none of these sesquiterpenes is under clinical evaluation. Some studies have also reported the ability of plant-derived caryophyllane sesquiterpenes to affect the immune system, thus suggesting that their immunomodulation can represent a mechanism that accounts for their bioactivities.

The immune system plays a central role in the maintenance of body homeostasis as it is able to protect against damage by viruses, bacteria, and any other foreign agents (e.g., xenobiotics and environmental pollutants) through the activation of both innate (or native immunity) and adaptive functions [7]. The immunity functions involve different 
specialized immune cells, also known as leukocytes, among which granulocytes (e.g., neutrophils, basophils, and eosinophils), monocytes (e.g., macrophages and dendritic cells) and lymphocytes (i.e., T- and B-lymphocytes), and natural killer (NK) cells [8]. Mast cells, phagocytes, dendritic cells, and NK (natural killer) are the central actors of innate immunity and provide the first physical and biochemical defense barrier, while adaptive immunity involves specialized lymphocytes, which are responsible for the release of protective molecules, such as cytokines, chemokines, and high-affinity antibodies, and for immunological memory [9].

Under normal conditions, the immune system is highly specific and tightly regulated; however, host protective immune responses can be disrupted by pathogens, to favor the disease progression, creating a greater risk of health complications. For instance, some viruses (e.g., HIV, the hepatitis B virus, or the hepatitis C virus) are able to block immune checkpoints, thus limiting host-protective antigen-specific immune responses and favoring disease progression [10]; moreover, most parasites and bacteria are not cleared by the host due to pathogen-mediated immune subversion strategies which lead to chronic infections [11]. An abnormal B-cell and T-cell recognition of self-antigens, which leads to the release of self-reactive antibodies, can also occur in autoimmune diseases, such as psoriasis, lupus erythematosus, and multiple sclerosis [12]. Likewise, aberrant innate immune responses can cause episodic spontaneous inflammation, affecting multiple organ systems [13].

Several studies have highlighted the immune system alterations in metabolic disorders, such as diabetes and obesity, including neutrophil degranulation impairments [14], defects in reactive oxygen species production [15], and decreased phagocytosis [16]; moreover, an inflammatory immune response, due to adipocyte apoptosis and macrophage infiltration, has been reported in hyperglycemia and diabetes $[17,18]$. Hyperglycemia may also alter the macrophage function because of the reduced glycolytic capacity and long-term sensitization to high glucose levels [19].

Various brain diseases are deemed to be linked to "low-grade immune activation", characterized by enhanced levels of circulating pro-inflammatory cytokines and migration of myeloid immune cells [20]; moreover, the role of microglia, which represent the only immune cells that permanently reside in the central nervous system, in maintaining normal brain physiology and its implication in neuroinflammation and neurodegeneration has been highlighted [21].

A crucial control by the immune system has been also found in cancer development and progression; indeed, specific antigens on cancer cells can activate an anti-tumor immune response, which can destroy the tumor; moreover, concomitant immunosuppressive responses can be mediated by regulatory $\mathrm{T}$ cells (Tregs) and the stromal microenvironment [22]. The interest in the cancer control by the immune system has led to the development of cancer immunotherapies, characterized by high efficacy and specificity $[23,24]$, though with undeniable limitations and challenges, which require future research to be overcome.

Altogether, this evidence suggests an interest in studying the modulation of the immune system by plant-based caryophyllane sesquiterpenes as a possible mechanism to account for their protective and chemopreventive properties and which could be exploited in combination with well-approved therapies.

\section{Methodology}

To understand the ability of plant-based caryophyllane sesquiterpenes (i.e., $\beta$-caryophyllene, $\beta$-caryophyllene oxide, $\alpha$-humulene, and isocaryophyllene) to modulate the immune system function, a systematic review of the existing literature in PubMed, Scopus, and Web of Science databases was performed using the PRISMA (Preferred Reporting Items for Systematic Reviews and Meta-Analysis) methodology [25].

The databases were searched in December 2021 to select journal articles over a 20-year period (January 2001 to December 2021), focused on the effect of caryophyllane sesquiter- 
penes on the immune system and the mechanisms involved. English was chosen as the preferred language. The keywords "caryophyllene", "caryophyllene oxide", "humulene", "isocaryophyllene", "immune system", "macrophage", "lymphocyte", and "microglia" and their combinations through the Boolean logical operator "AND" were used. As regards the research strategy, the studies highlighting the effects of $\beta$-caryophyllene, $\beta$ caryophyllene oxide, $\alpha$-humulene, and isocaryophyllene on the immune system function have been included; conversely, those focused on herbal extracts or essential oils containing caryophyllane sesquiterpenes, but not the pure compounds, were excluded. Other studies in which the purity of caryophyllane sesquiterpenes was low $(<90 \%)$ or not specified, and those assessing other substances or diverse bioactivities or lacking data were excluded too.

\section{Results}

The literature search revealed the presence of a total of 504 published papers focused on the effect of the caryophyllane sesquiterpenes $\beta$-caryophyllene, $\beta$-caryophyllene oxide, $\alpha$-humulene, and isocaryophyllene on the immune system (Figure 1). Among them, 49 records were removed, being publications other than journal articles, while 224 were replicates in the searched databases.

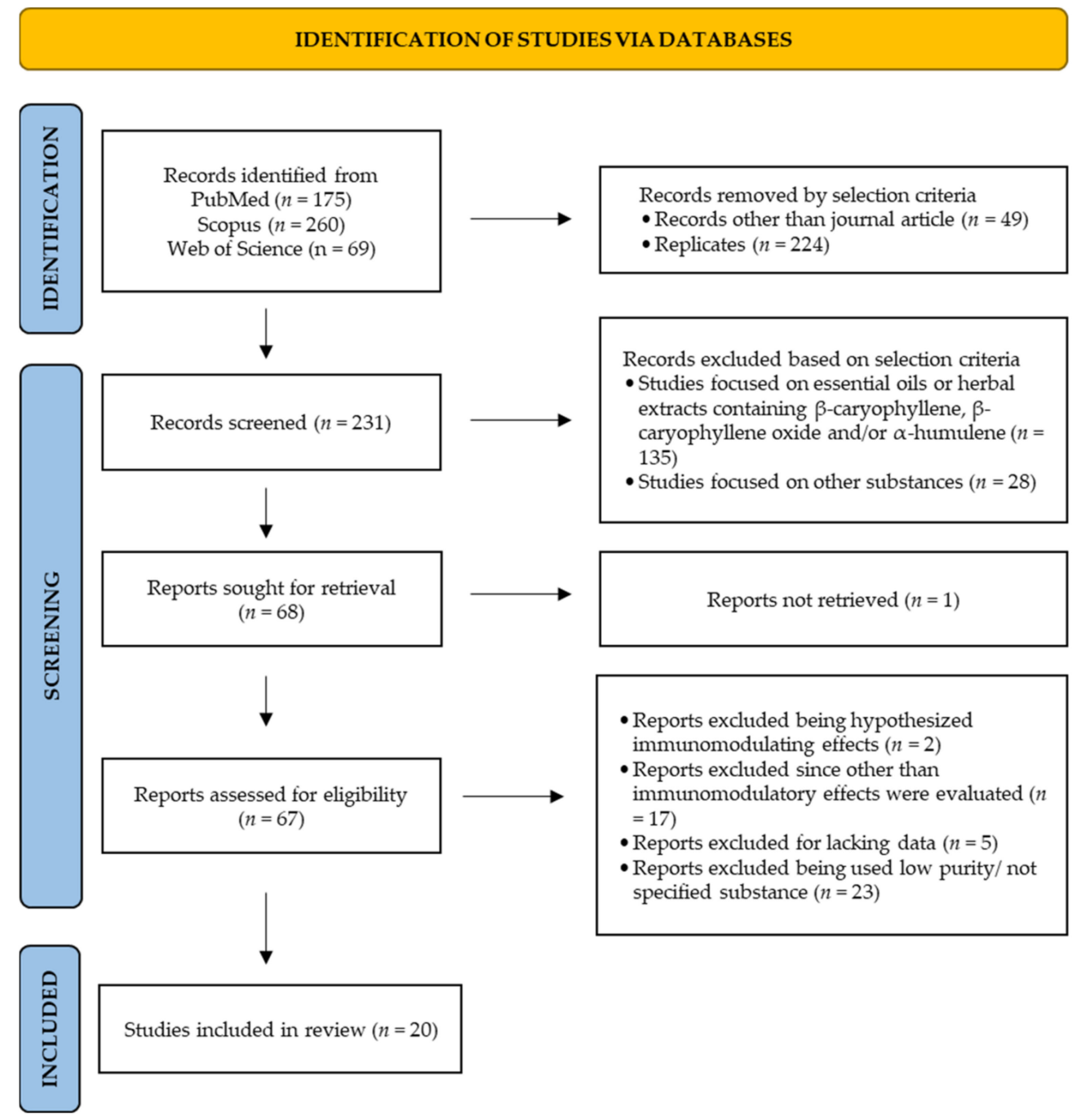

Figure 1. Study selection by PRISMA flow diagram for the immunomodulatory activity of caryophyllane sesquiterpenes.

Out of the 231 records screened, none investigated the effects of isocaryophyllene on the immune system, while 135 papers were focused on essential oils or herbal extracts 
containing $\beta$-caryophyllene, $\beta$-caryophyllene oxide and/or $\alpha$-humulene and 28 were on other substances: these latter papers were excluded as the selection criteria were not accomplished. Among the 67 eligible papers, 19 reports were excluded as other bioactivities of caryophyllane sesquiterpenes were evaluated or their immunomodulating effects were hypothesized $(n=2)$; moreover, 5 studies were excluded for lacking data, and 23 were excluded as they used caryophyllane sesquiterpenes of low purity $(<90 \%$ purity) or unspecified purity. Based on the PRISMA analysis, a total of 20 studies was included in this review.

The selected studies showed that the immunomodulatory properties of caryophyllane sesquiterpenes have been investigated in different immune cells (i.e., microglia, macrophages, lymphocytes, monocytes, and neutrophils) and in some animal models of disease; $\beta$-caryophyllene was the most studied compound, followed by $\alpha$-humulene and $\beta$-caryophyllene oxide (Figure 2). For instance, the modulation of microglia by $\beta$ caryophyllene in neurodegenerative diseases has been associated with its neuroprotective properties, while attenuation of lymphocyte autoreactivity has been approached as a possible strategy against autoimmune diseases. In line with this evidence, the ability of caryophyllane sesquiterpenes to modulate the immune cell function has been described, and possible future developments have been highlighted.

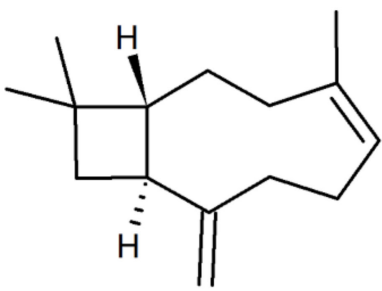

$\beta$-Caryophyllene

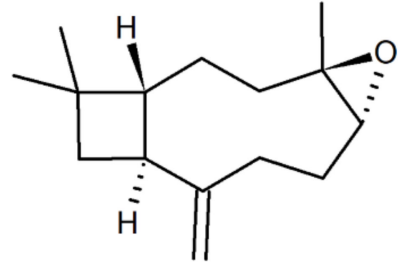

$\beta$-Caryophyllene oxide

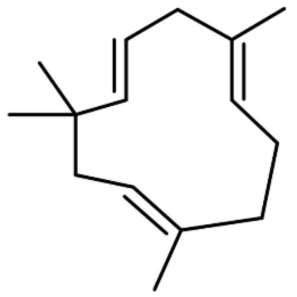

$\alpha$-Humulene

Figure 2. Chemical structures of plant-based caryophyllane sesquiterpenes with immunomodulatory properties.

\subsection{Ability of Caryophyllane Sesquiterpenes to Modulate Macrophage Function}

Macrophages are mononuclear phagocytes that compose a heterogeneous population of immune cells, whose major functions are antigen presentation, cytokine production, phagocytosis, and the processing of foreign materials, including pathogens [26]. Due to their highly effective phagocytic capacity, they are deemed to be "professional" phagocytic cells, along with monocytes, dendritic cells, neutrophils, and mast cells [27]. Specialized macrophages can be identified in tissues and can be subdivided into two main classes, including tissue resident and infiltrated macrophages [27]. The first ones, such as the microglia in the central nervous system (CNS), Langerhans cells in the skin, Kupffer cells in the liver, osteoclasts in the bone, and alveolar macrophages in the lung, are present in tissues under homeostatic conditions and regulate homeostasis, tissue development, remodelling, and repair [27]. Infiltrated macrophages are pro-inflammatory cells, recruited from the blood into inflamed tissues and arise from circulating monocyte differentiation [27,28]. Both resident and recruited macrophages can be polarized into different phenotypes in response to the local tissue microenvironment and several stimuli and participate in the homeostasis modulation and inflammation response. Indeed, they can switch from a pro-inflammatory M1 phenotype to a M2 anti-inflammatory one: the first phenotype is activated in response to lipopolysaccharide (LPS), $\gamma$-interferon (IFN- $\gamma$ ), tumor necrosis factor alpha (TNF- $\alpha$ ), and granulocyte/macrophage colony-stimulating factor (GM-CSF), while the M2 phenotype is induced by interleukin-4 (IL-4), IL-10, IL-13, transforming growth factor- $\beta$ (TGF- $\beta$ ), and macrophage colony-stimulating factor (M-CSF). The polarization of macrophages depends on a complex regulation in which different pathways are involved, including signal transducer and activator of transcription (STAT) and the peroxisome proliferator-activated receptor- $\gamma(\operatorname{PPAR} \gamma)$, and cytokines, released by both the 
M1 and the M2 macrophages with both pro-inflammatory and anti-inflammatory functions [29]. The M1 macrophages have potent antimicrobial and anti-tumor activities and the ability to release pro-inflammatory cytokines and chemokines, leading to the exacerbation of inflammation and tissue damage [28]. Conversely, the M2 macrophages possess a potent phagocytic capacity and anti-inflammatory and immunosuppressive properties, which contribute to the resolution of inflammation and tissue repair [26,28]. Macrophages can also modulate painful conditions, acting as nociceptor activators or favouring pain resolution, through the release of pro-inflammatory mediators (e.g., ROS, cytokines, and chemokines such as prostaglandin E2 (PGE2), IL-1 $\beta$, and TNF- $\alpha$ ) and analgesic factors (e.g., $\beta$-endorphin), respectively [26].

Modulation of macrophage function by caryophyllane sesquiterpenes has been evaluated in both in vitro models, such as murine RAW 264.7 macrophages, primary splenocytes from BALB/c mice, and M2-MФs BALB/c mice bone-marrow-derived M2 macrophage, and in vivo (Table 1). Yamaguchi et al. [30] found that $\beta$-caryophyllene was nontoxic in RAW 264.7 macrophages at the concentrations of 10 and $50 \mu \mathrm{M}$ after a 3-day exposure, although the expression of the key proteins involved in cell proliferation was affected by the treatment with $50 \mu \mathrm{M}$ of the test substance (Table 1); indeed, a lowering in the mitogenactivated protein kinases (MAPK) levels and an increase in Ras, protein kinase B(Akt), p21, $\beta$-catenin, and caspase-3, involved in apoptotic cell death, was found. A 3-day exposure to $10 \mu \mathrm{M} \beta$-caryophyllene reduced the levels of proinflammatory cytokines, including TNF- $\alpha$, PGE-2, and IL-6 in RAW 264.7 cells; in particular, TNF- $\alpha$ was reduced both with and without LPS, while a lowering in PGE-2 and IL-6 levels occurred in the absence and presence of LPS, respectively [30]. In the same study, $\beta$-caryophyllene improved the reduction of the macrophage number induced by metaxalone [30]. Similarly, Yamaguchi et al. [31] have found that a short $5 \mathrm{~h}$ exposure to a low concentration $(5 \mu \mathrm{M})$ of $\beta$-caryophyllene counteracted the LPS-induced release of pro-inflammatory cytokines without affecting the basal levels of IL-1 $\beta$, IL-6, and TNF- $\alpha$, but lowered them after LPS stimulation. Similarly, a $48 \mathrm{~h}$ exposure to $\alpha$-humulene, at concentrations of 755 and $1555 \mu \mathrm{M}$, inhibited the inflammatory response induced by LPS, by lowering the release of nitric oxide (NO), in murine macrophages RAW 264.7 [32]. Ku and colleagues studied the modulation of cytokine release induced by LPS in primary splenocytes from BALB/c mice by a $48 \mathrm{~h}$ exposure to $\beta$-caryophyllene, $\beta$-caryophyllene oxide, and $\alpha$-humulene $(0.25-25 \mu \mathrm{M})$ [33]. In particular, $\beta$-caryophyllene was able to lower the levels of both IL-1 and IL-10, which are responsible for pro-inflammatory and anti-inflammatory effects, respectively; moreover, an increase in the Thelper cell type 2/1 (Th2/Th1) ratio, associated with anti-inflammatory effects, was found too. Similarly, $\beta$-caryophyllene oxide counteracted the LPS-induced inflammation by decreasing the IL-2 levels; by contrast, no effects were highlighted for $\alpha$-humulene [33].

Macrophages and monocytes take part in the tumor microenvironment and favor tumor progression through the release of pro-inflammatory cytokines and pro-angiogenic factors; indeed, both tissue-resident macrophages and infiltrated monocytes can give rise to TAM (tumor-associated macrophages), involved in tumor progression [34]. TAM impairs immune the anti-tumor defense and anti-inflammatory response by suppressing the T cells [34] and M2 macrophages [27], while monocyte-derived TAM promotes angiogenesis [34]. Moreover, both the M1 and the M2 macrophages can contribute to cancer development and progression [27]. In this context, Jung et al. [35] evaluated the ability of $\beta$ caryophyllene to block the progression of melanoma by affecting macrophage accumulation in tumor tissue (Table 1). To this end, a co-culture model of activated macrophages (M2$\mathrm{M} \Phi \mathrm{s})$, obtained by murine bone-marrow monocytes exposed to IL-4, mature adipocytes (Mas), and melanoma B16F10s cells was used. Including adipocytes in the cell model is due to the known role of adipose tissue in melanoma progression [35]; indeed, being near the skin, it influences crosstalk between the macrophages and the tumor cells and contributes to tissue inflammation by the release of pro-inflammatory cytokines, as often found in obesity. This disease is also characterized by a chronic and low-grade inflammatory condition, which is supported by a switch to the M1 macrophage phenotype and a recruitment of B and 
$\mathrm{T}$ cells, induced by several factors released by adipose tissue, such as $\mathrm{C}-\mathrm{C}$ motif chemokine ligand 2 (CCL2) and Toll-like receptor 4 (TLR4) [27,29]. Jung et al. [35] found that a $24 \mathrm{~h}$ exposure to $5 \mu \mathrm{M} \beta$-caryophyllene decreased MCP-1 (monocyte chemoattractant protein-1) and M-CSF (macrophage-colony stimulating factor) levels in the medium of M2-MФs, Mas, and B16F10s, thus suggesting the ability of the compound to lower the macrophage accumulation in tumor tissue and thus limiting the inflammatory conditions that support tumor progression. A reduction in macrophage recruitment by $\beta$-caryophyllene was confirmed by the inhibition of their migration when the medium of MAs and B16F10s cells was used as a chemoattractant [35].

Similar results were obtained in an in vivo model of melanoma induced in high-fat diet mice (Table 2) [35]. $\beta$-Caryophyllene was administered to mice as 0.15 or $0.3 \%$ of a $60 \mathrm{kcal} \%$ fat diet; the B16F10 melanoma cells were injected. The fat diet increased the number of macrophage (M $\Phi$ ) and macrophage mannose receptors (MMR) in the tumor tissues and adipose tissues surrounding the lymph nodes, with respect to a control $10 \mathrm{kcal} \%$ fat diet. Conversely, the $\beta$-caryophyllene was able to suppress macrophage infiltration both in tumor and in adipose tissues; these effects were associated with a lowering in the lymphocyte population in the tumor tissue and in the levels of CCL19 and CCL21 cytokines, which represent critical regulators in T-cell activation, immune tolerance, and inflammatory responses. These results highlight the ability of $\beta$-caryophyllene to inhibit tumor growth and lymph node metastasis, probably through suppressing the immune response induced by lipid accumulation.

A lowering in the macrophage infiltration by $\beta$-caryophyllene was also highlighted in other in vivo models of disease, such as atherosclerosis, nephropathy, and colitis (Table 2). In particular, Zhang et al. [36] showed that $\beta$-caryophyllene $(10 \mathrm{mg} / \mathrm{kg})$ was able to inhibit macrophage infiltration in the aortic surface by blocking the induction of vascular cell adhesion molecule-1 (VCAM-1). Moreover, Horváth and colleagues [37] found that $\beta$ caryophyllene $(10 \mathrm{mg} / \mathrm{kg}$ i.p.) lowered macrophage and neutrophil infiltration, along with leucocyte levels, in a murine model of nephropathy induced by cisplatin. This effect was likely due to a cannabinoid receptor 2 (CB2) modulation by the sesquiterpene; indeed, the response was completely abolished in CB2 receptor knockout mice. $\beta$-Caryophyllene ( $50 \mathrm{mg} / \mathrm{kg}$ by gavage) was also reported able to reduce the colon infiltration of macrophages and neutrophiles in dextran sulfate sodium (DSS)-induced CD1 mice colitis, probably by inhibiting inflammation through the activation of the CB2 and PPAR-gamma receptors [38]. $\beta$-Caryophyllene has been also studied for its ability to affect the function of microglial cells; by contrast, lower or null evidence is available for $\beta$-caryophyllene oxide and $\alpha$ humulene. Microglial cells are specialized macrophages which reside in the central nervous system and play a crucial protective role in nervous tissue [39]. Microglia are also involved in neurodegenerative processes, such as Alzheimer's disease, Parkinson's disease, and multiple sclerosis, being able to support tissue inflammation by switching to the M1 inflammatory phenotype; indeed, over-activation of the M1 phenotype markedly increases the release of inflammatory mediators, such as the nuclear factor $\mathrm{kB}(\mathrm{Nf}-\mathrm{kB})$, and oxidative stress, leading to neuronal injury [39]. Usually, the M2 polarization of microglia occurs initially as a consequence of a neuronal injury, such as an ischemic stroke, and promotes tissue repair through the release of anti-inflammatory mediators, such as IL-10 and IL4 [40]. Thereafter, it switches to the M1 pro-inflammatory phenotype, which induces neuroinflammation and tissue damage [41]. 
Table 1. Effects of caryophyllane sesquiterpenes in in vitro models of immune cells.

\begin{tabular}{|c|c|c|c|c|c|}
\hline $\begin{array}{l}\text { Caryophyllane } \\
\text { Sesquiterpene }\end{array}$ & $\begin{array}{l}\text { Immune System } \\
\text { Cells/Cell Model }\end{array}$ & Stimulation & $\begin{array}{c}\text { Concentration of } \\
\text { Test Compound } \\
{[\mu \mathrm{M}]}\end{array}$ & Outcome & References \\
\hline \multirow{16}{*}{$\beta$-Caryophyllene } & \multirow{6}{*}{$\begin{array}{l}\text { Macrophages/ } \\
\text { RAW 264.7 }\end{array}$} & - & 10,50 & $\begin{array}{l}\text { Lacking effects on cell } \\
\text { viability }\end{array}$ & \multirow{4}{*}{ [30] } \\
\hline & & - & 50 & $\begin{array}{c}\text { Ras, Akt, p21, } \beta \text {-catenin, } \\
\text { caspase- } 3 \\
\downarrow \text { MAPK }\end{array}$ & \\
\hline & & - & 10 & $\begin{array}{c}\downarrow \text { TNF- } \alpha \text { and PGE2 } \\
\text { Lacking effect on IL-6 }\end{array}$ & \\
\hline & & $\begin{array}{c}\text { LPS }^{\mathrm{a}} \\
{[100 \mathrm{ng} / \mathrm{mL}]}\end{array}$ & 10 & $\begin{array}{c}\downarrow \text { TNF- } \alpha \text { and IL-6 } \\
\text { Lacking effect on PGE2 }\end{array}$ & \\
\hline & & - & 5 & $\begin{array}{l}\text { Lacking effect on IL-1 } \beta \text {, } \\
\text { IL-6, TNF- } \alpha\end{array}$ & \multirow{2}{*}{ [31] } \\
\hline & & $\begin{array}{c}\text { LPS }^{\mathrm{a}} \\
{[100 \mathrm{ng} / \mathrm{mL}]}\end{array}$ & 5 & $\downarrow$ IL-1 $\beta$, IL-6, TNF- $\alpha$ & \\
\hline & $\begin{array}{l}\text { Macrophages/primary } \\
\text { splenocytes from } \\
\text { BALB/c mice }\end{array}$ & $\begin{array}{c}\text { LPS }^{\mathrm{b}} \\
{[2.5 \mu \mathrm{g} / \mathrm{mL}]}\end{array}$ & $0.25-25$ & $\begin{array}{l}\downarrow \text { IL-1, IL-10 } \\
\uparrow \text { Th2/Th1 ratio }\end{array}$ & [33] \\
\hline & \multirow{2}{*}{$\begin{array}{l}\text { Macrophages/ } \\
\text { M2-Mథs } \\
\text { (co-cultured) }\end{array}$} & - & 5 & $\begin{array}{l}\downarrow \mathrm{MCP}-1, \mathrm{M}-\mathrm{CSF} \\
\text { and migration }\end{array}$ & {$[35]$} \\
\hline & & $\begin{array}{c}\text { LPS }^{\mathrm{c}} \\
{[1 \mu \mathrm{g} / \mathrm{mL}]}\end{array}$ & $0.2-50$ & Cytoprotection & \multirow[b]{2}{*}{ [40] } \\
\hline & $\begin{array}{l}\text { Microglia/C57BL/6 } \\
\text { mice cells }\end{array}$ & $\begin{array}{c}\text { LPS c }^{c} \\
{[1 \mu \mathrm{m} / \mathrm{mL}]}\end{array}$ & $0.2-25$ & $\begin{array}{c}\downarrow \text { TNF- } \alpha, \text { IL- } \beta, \text { PGE2, NO } \\
\text { ad iNOS } \\
\uparrow \text { IL-10, Arg- } 1 \text {, urea } \\
\text { and GSH }\end{array}$ & \\
\hline & $\begin{array}{l}\text { Microglia/ } \\
\text { BV2 cells }\end{array}$ & $\begin{array}{l}\mathrm{A} \beta_{1-42} \\
{[20 \mu \mathrm{M}]}\end{array}$ & $10,25,50$ & $\begin{array}{c}\downarrow \text { IL- } \beta, \text { IL-6, TNF- } \alpha, \text { NO, } \\
\text { PGE2, TLR4, LDH, Nf-kB } \\
\text { iNOS and } \\
\text { COX-2 inhibition }\end{array}$ & [42] \\
\hline & $\begin{array}{l}\text { Monocytes/ } \\
\text { THP-1 }\end{array}$ & $\mathrm{TNF}-\alpha^{\mathrm{d}}$ & 5 & $\begin{array}{c}\downarrow \text { VCAM-1, adhesion on } \\
\text { HUVECs }\end{array}$ & {$[36]$} \\
\hline & $\begin{array}{l}\text { Monocytes/primary } \\
\text { monocytes CD14+ }\end{array}$ & $\begin{array}{c}\text { LPS }^{\mathrm{a}} \\
{[313 \mathrm{ng} / \mathrm{mL}]}\end{array}$ & 0.5 & $\begin{array}{c}\downarrow \text { TNF- } \alpha \text { and IL-1 } \beta \\
\text { Lacking effects on IL-6 } \\
\text { and IL-10 levels } \\
\downarrow \text { Erk } 1 / 2 \text { and JNK } 1 / 2 \\
\text { activation } \\
\text { Lacking effects on MAPK } \\
\text { p38 activation } \\
\end{array}$ & [43] \\
\hline & \multirow[t]{2}{*}{$\begin{array}{l}\text { Lymphocytes/ } \\
\text { isolated cells from } \\
\text { EAE mice }\end{array}$} & $\begin{array}{l}\mathrm{MOG}_{35-55} \\
{[30 \mu \mathrm{g} / \mathrm{mL}]}\end{array}$ & $0.2,1$ & $\begin{array}{c}\downarrow \text { cellular proliferation } \\
\downarrow \text { IFN } \gamma, \text { IL-17, IFN } \gamma / \text { IL-4 } \\
\text { ratio, IL17/IL10 ratio } \\
\uparrow \text { IL-4, IL-10 }\end{array}$ & {$[44]$} \\
\hline & & $\begin{array}{c}\mathrm{MOG}_{35-55} \\
{[10 \mu \mathrm{g} / \mathrm{mL}]}\end{array}$ & $1-100$ & $\begin{array}{c}\uparrow \text { IL-10, } \downarrow \text { IFN } \gamma \\
\text { Lacking effects on IL-4 }\end{array}$ & {$[45]$} \\
\hline & $\begin{array}{l}\text { Lymphocytes/ } \\
\text { isolated cells from } \\
\text { healthy donors }\end{array}$ & - & $0.5-500$ & Genoprotective effects & {$[46]$} \\
\hline \multirow{3}{*}{$\begin{array}{l}\beta \text {-Caryophyllene } \\
\text { oxide }\end{array}$} & $\begin{array}{l}\text { Macrophages/ } \\
\text { primary splenocytes } \\
\text { from BALB/c mice }\end{array}$ & $\begin{array}{c}\mathrm{LPS}^{\mathrm{b}} \\
{[2.5 \mu \mathrm{g} / \mathrm{mL}]}\end{array}$ & $0.25-25$ & $\downarrow \mathrm{IL}-2$ & {$[33]$} \\
\hline & Lymphocytes/ & - & $1-100$ & Lacking genotoxic effects & \multirow{2}{*}[47]{} \\
\hline & $\begin{array}{l}\text { 1solated from } \\
\text { healthy donors }\end{array}$ & - & 250 and 500 & Cytotoxic effects & \\
\hline
\end{tabular}


Table 1. Cont.

\begin{tabular}{|c|c|c|c|c|c|}
\hline $\begin{array}{l}\text { Caryophyllane } \\
\text { Sesquiterpene }\end{array}$ & $\begin{array}{l}\text { Immune System } \\
\text { Cells/Cell Model }\end{array}$ & Stimulation & $\begin{array}{c}\text { Concentration of } \\
\text { Test Compound } \\
{[\mu \mathrm{M}]}\end{array}$ & Outcome & References \\
\hline \multirow{3}{*}{$\alpha$-Humulene } & $\begin{array}{l}\text { Macrophages/ } \\
\text { RAW } 264.7\end{array}$ & $\begin{array}{c}\text { LPS a } \\
{[1 \mu \mathrm{g} / \mathrm{mL}]}\end{array}$ & 755,1555 & $\downarrow \mathrm{NO}$ & {$[32]$} \\
\hline & $\begin{array}{l}\text { Macrophages/primary } \\
\text { splenocytes from } \\
\text { BALB/c mice }\end{array}$ & $\begin{array}{c}\text { LPS }^{b} \\
{[2,5 \mu \mathrm{g} / \mathrm{mL}]}\end{array}$ & $0.25-25$ & $\downarrow$ IL-10 & [33] \\
\hline & Lymphocytes/MLNs & $\begin{array}{c}\text { OVA } \\
{[50 \mu \mathrm{g} / \mathrm{mL}]}\end{array}$ & 1,10 & $\downarrow$ IL-5 & {$[48]$} \\
\hline \multicolumn{6}{|c|}{ 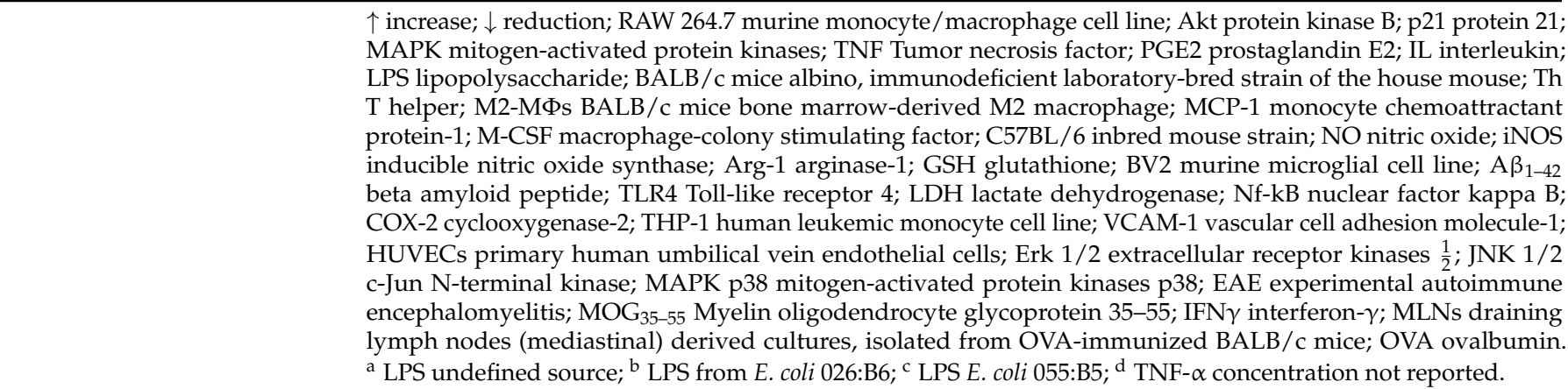 } \\
\hline
\end{tabular}

The activation of M1 microglia has been associated with the dopaminergic neurodegeneration occurring in Parkinson's disease [39]; similarly, in Alzheimer's disease, the M1 microglia are recruited around senile plaques, due to beta-amyloid (A $\beta$ ) stimulation, leading to the release of pro-inflammatory cytokines and to neurotoxicity and neuronal death [42]. These cells surrounding senile plaques were found to express high levels of CB2 receptors, suggesting a potential interest in CB2 agonists in the treatment of Alzheimer's disease [42]. Both in vitro and in vivo evidence suggests the ability of $\beta$-caryophyllene to block the microglia activation of the pro-inflammatory phenotype; this effect was mainly ascribed to a modulation of the CB2 receptors, widely expressed in immune system cells, and of several pathways and factors, such as TLRs, PPAR- $\gamma$, and Nf-kB [40].

$\beta$-Caryophyllene showed a positive modulation of the microglia M1/M2 imbalance induced by several agents, such as LPS and $\beta$-amyloid, thus suggesting its possible ability to ameliorate neuroinflammation in Alzheimer's disease and multiple sclerosis. In particular, when assessed in microglial cells isolated from mouse brains, the sesquiterpene $(0.2-50 \mu \mathrm{M})$ showed a counteraction of the effects of LPS $(1 \mu \mathrm{g} / \mathrm{mL})$ by enhancing cell proliferation via activation of the CB2 and PPAR $\gamma$ receptors [40]. These effects were confirmed by the loss of protective effects in the presence of selective CB2 and PPAR $\gamma$ receptor antagonists (AM630 and GW9662, respectively); conversely, a co-treatment with imipramine, which is a known inhibitor of sphingomyelinase (SMase), potentiated the increased proliferation of microglial cells, thus suggesting a role of this enzyme in the LPS-induced damage [40]. Under the same experimental model, $\beta$-caryophyllene $(0.2-25 \mu \mathrm{M})$ produced anti-inflammatory effects via CB2 and PPAR $\gamma$ receptor activation by counteracting the LPS-induced increase in TNF- $\alpha$, IL-1 $\beta$, PGE2, inducible nitric oxide synthase (iNOS), and NO and increased the levels of anti-inflammatory mediators, such as IL-10, urea, and Arginase-1 (Arg-1), which was negatively affected by LPS; antioxidant effects, with decreased ROS levels and enhanced glutathione (GSH) ones, were found too [40]. The authors highlighted that the beneficial anti-inflammatory and antioxidant effects of $\beta$-caryophyllene can be improved by inhibiting the SMase enzyme; moreover, the activation of the nuclear factor erythroid 2-related factor/heme oxygenase-1 (Nrf2/HO-1) signaling is hypothesized. On the basis of these findings, an involvement of ceramides in the protective properties of the sesquiterpene has been suggested. Indeed, ceramides, which are PPAR- $\gamma$ receptor activators [49], arise from sphingomyelinase (SMase) activity, which is stimulated by CB2activated $\beta \gamma$-subunit [50]. An overproduction of ceramides, due to the CB2 activation 
induced by middle and higher concentrations of $\beta$-caryophyllene, can stimulate the PPAR- $\gamma$ pathway and thus further contribute to the protective activity of $\beta$-caryophyllene [40].

$\beta$-caryophyllene also showed modulatory effects on microglial activity in in vitro models of Alzheimer's disease by counteracting the toxic effects of $A \beta_{1-42}$ soluble oligomers, known to be responsible for direct neurotoxicity and for indirect neuroinflammation. $\mathrm{Hu}$ and colleagues [42] showed that $\beta$-caryophyllene $(10,25$, and $50 \mu \mathrm{M})$ was able to protect BV2 microglial cells from $A \beta_{1-42}(20 \mu \mathrm{M})$ injury by lowering the release of LDH and inflammation, through the impairment of TLR4/Nf-kB signaling, involved in brain inflammatory response. Indeed, it inhibited the iNOS and cyclooxygenase-2 (COX-2) enzymes and their products and the gene expression of pro-inflammatory cytokines (TNF- $\alpha$, IL-6, and IL- $1 \beta$ ); moreover, a decreased expression of TLR4, involved in the progression of Alzheimer's disease, and M1 polarization [40], along with a reduced Nf-kB activity, due to the inhibition of IKB $\alpha$ phosphorylation and degradation, were found too [42].

Table 2. Immunomodulatory effects of caryophyllane sesquiterpenes in animal models of disease.

\begin{tabular}{|c|c|c|c|c|}
\hline $\begin{array}{l}\text { Caryophyllane } \\
\text { Sesquiterpene }\end{array}$ & $\begin{array}{l}\text { Animal Model/ } \\
\text { Immune Cells }\end{array}$ & $\begin{array}{l}\text { Test Compound Dose } \\
\text { (Administration Route) }\end{array}$ & Outcome & References \\
\hline \multirow{15}{*}{$\beta$-Caryophyllene } & $\begin{array}{c}\text { High-fat diet and } \\
\text { B16F10 bearing } \\
\text { C57BL/6 mice/macrophages }\end{array}$ & $0.15-0.3 \%$ of diet (per os) & $\begin{array}{c}\downarrow \text { macrophages in tumor tissue } \\
\downarrow \text { macrophages in the } \\
\text { lymphnode }\end{array}$ & [35] \\
\hline & $\begin{array}{l}\text { LPS-fat-induced atherosclerosis } \\
\text { C57BL/ } 6 \text { mice/macrophages }\end{array}$ & 10 mg/kg (i.p.) & $\begin{array}{c}\downarrow \text { macrophage infiltration to } \\
\text { the aortic surface }\end{array}$ & [36] \\
\hline & $\begin{array}{l}\text { Alcoholic steatohepatitis } \\
\text { C57BL/6J mice/macrophages }\end{array}$ & 10 mg/kg (i.p.) & $\downarrow$ CXCL2, TNF- $\alpha$ & [51] \\
\hline & $\begin{array}{l}\text { Cisplatin-induced nephrotoxicity } \\
\text { C57BL/6J mice/macrophages }\end{array}$ & 10 mg/kg (i.p.) & $\downarrow$ macrophage infiltration & [37] \\
\hline & $\begin{array}{c}\text { DSS-induced colitis } \\
\text { CD1 mice/macrophages }\end{array}$ & $\begin{array}{l}12-50 \mathrm{mg} / \mathrm{kg} \text { (per os; } \\
\text { gavage) }\end{array}$ & $\downarrow$ infiltration in colon & [38] \\
\hline & EAE C57BL/ 6 mice/microglia & $5 \mathrm{mg} / \mathrm{kg}$ (per os) & $\begin{array}{l}\downarrow \text { TNF- } \alpha, \text { PGE2, iNOS, NO, } \\
\text { iNOS/Arg1, NO/urea } \\
\uparrow \text { IL-10, Arg-1, urea }\end{array}$ & [44] \\
\hline & EAE C57BL/ 6 mice/microglia & $50 \mathrm{mg} / \mathrm{kg}$ (per os; gavage) & $\downarrow$ Activation microglia & [45] \\
\hline & $\begin{array}{l}\text { Rotenone-induced Parkinson's } \\
\text { disease in Wistar rats/microglia }\end{array}$ & 50 mg/kg (i.p.) & $\begin{array}{c}\downarrow \text { Activation microglia } \\
\downarrow \text { Iba- } 1\end{array}$ & [52] \\
\hline & EAE C57BL/6 mice/leucocytes & $5 \mathrm{mg} / \mathrm{kg}$ (per os) & $\downarrow$ leucocytes in spinal cord & [44] \\
\hline & $\begin{array}{l}\text { Cisplatin-induced nephrotoxicity } \\
\text { C57BL/6J mice/leucocytes }\end{array}$ & 10 mg/kg (i.p.) & $\downarrow$ leucocytes infiltration & [37] \\
\hline & $\begin{array}{l}\text { High-fat diet and B16F10-bearing } \\
\text { C57BL/6 mice/leucocytes }\end{array}$ & $0.15-0.3 \%$ of diet (per os) & $\downarrow$ lymphocytes in tumor tissue & [35] \\
\hline & EAE C57BL/6 mice/lymphocytes & $5 \mathrm{mg} / \mathrm{kg}$ (per os) & $\begin{array}{c}\downarrow \text { cell proliferation } \\
\uparrow \text { IL-4, IL-10, TGF- } \beta \text {, GATA-3 } \\
\downarrow \text { TNF- } \alpha \text {, IL-6, IFN } \gamma \text {, IL-17, } \\
\text { T-bet, T-bet/GATA3 } \\
\text { (Th1/Th2) }\end{array}$ & [44] \\
\hline & EAE C57BL/ 6 mice/lymphocytes & $50 \mathrm{mg} / \mathrm{kg}$ (per os; gavage) & $\begin{array}{c}\downarrow \mathrm{CD} 4+\text { and CD8+ T cells } \\
\downarrow \text { CD4+ and CD8+ T cells in } \\
\text { peripheral lymphoid tissue } \\
\text { Inhibition of Th1 } \\
\text { myelin-specific cells in CNS }\end{array}$ & [45] \\
\hline & $\begin{array}{l}\text { OVA-induced airway allergic } \\
\text { inflammation BALB/c } \\
\text { mice/lymphocytes }\end{array}$ & $50 \mathrm{mg} / \mathrm{kg}$ (per os) & $\begin{array}{l}\text { Lacking effects on } \\
\text { lymphocytes infiltration }\end{array}$ & [48] \\
\hline & $\begin{array}{l}\text { Alcoholic steatohepatitis } \\
\text { C57BL/6J mice/neutrophils }\end{array}$ & 10 mg/kg (i.p.) & $\begin{array}{l}\downarrow \text { ICAM-1, E-selectin, } \\
\text { P-selectin }\end{array}$ & [51] \\
\hline
\end{tabular}


Table 2. Cont.

\begin{tabular}{|c|c|c|c|c|}
\hline $\begin{array}{l}\text { Caryophyllane } \\
\text { Sesquiterpene }\end{array}$ & $\begin{array}{l}\text { Animal Model/ } \\
\text { Immune Cells }\end{array}$ & $\begin{array}{l}\text { Test Compound Dose } \\
\text { (Administration Route) }\end{array}$ & Outcome & References \\
\hline & $\begin{array}{c}\text { Ehrlich ascites } \\
\text { BALB/c mice/natural killer cells }\end{array}$ & 20 mg/kg (i.p.) & $\begin{array}{l}\text { Restoration of NK cell activity } \\
\quad \text { (less potent than } \alpha \text {-HUM) }\end{array}$ & [52] \\
\hline & $\begin{array}{l}\text { DSS-induced colitis } \\
\text { CD1 mice/neutrophils }\end{array}$ & $\begin{array}{l}12-50 \mathrm{mg} / \mathrm{kg} \text { (per os; } \\
\text { gavage) }\end{array}$ & $\downarrow$ infiltration in colon & [38] \\
\hline & $\begin{array}{l}\text { LPS-induced paw inflammation in } \\
\text { Wistar rats/neutrophils }\end{array}$ & 50 mg/kg (per os) & $\downarrow$ infiltration of neutrophiles & [53] \\
\hline & $\begin{array}{l}\text { OVA-induced airway allergic } \\
\text { inflammation BALB/c } \\
\text { mice/eosinophils }\end{array}$ & $50 \mathrm{mg} / \mathrm{kg}$ (per os; gavage) & $\begin{array}{l}\text { Lacking effects on number of } \\
\text { eosinophils in BALF and on } \\
\text { eosinophil peroxidase activity }\end{array}$ & [48] \\
\hline \multirow{4}{*}{$\alpha$-Humulene } & $\begin{array}{c}\text { OVA-induced airway allergic } \\
\text { inflammation BALB/c } \\
\text { mice/leucocytes }\end{array}$ & $1 \mathrm{mg} / \mathrm{mL}$ (aerosol) & $\downarrow$ leucocyte counts in BALF & [48] \\
\hline & $\begin{array}{l}\text { LPS-induced paw inflammation in } \\
\text { Wistar rats/neutrophils }\end{array}$ & $50 \mathrm{mg} / \mathrm{kg}$ (per os) & $\downarrow$ neutrophils infiltration & [53] \\
\hline & \multirow[t]{2}{*}{$\begin{array}{l}\text { OVA-induced airway allergic } \\
\text { inflammation BALB/c } \\
\text { mice/eosinophils }\end{array}$} & 50 mg/kg (gavage) & $\begin{array}{c}\downarrow \text { eosinophils infiltration } \\
\downarrow \text { eosinophils, } \downarrow \text { peroxidase } \\
\text { activity, } \downarrow \text { CCL11, } \downarrow \text { IL-5 in } \\
\text { BALF }\end{array}$ & \multirow[t]{2}{*}{ [48] } \\
\hline & & $1 \mathrm{mg} / \mathrm{mL}$ (aerosol) & $\begin{array}{c}\downarrow \text { eosinophils, } \downarrow \text { peroxidase } \\
\text { activity, } \downarrow \text { CCL11, } \downarrow \text { IL-5 and } \uparrow \\
\text { IFN } \gamma \text { in BALF }\end{array}$ & \\
\hline
\end{tabular}

$\uparrow$ increase; $\downarrow$ reduction; B16F10 melanoma cells; C57BL/6 inbred mouse strain; LPS lipopolysaccharide; C57BL/6 inbred mouse strain; CXCL2 C-X-C Motif Chemokine Ligand 2; TNF tumor necrosis factor; DSS dextran sulfate sodium; CD1 outbred mice strain ; EAE experimental autoimmune encephalomyelitis; PGE2 prostaglandin E2; iNOS inducible nitric oxide synthase; NO nitric oxide; IL interleukin; Arg-1 arginase-1; Wistar Rats outbred albino rat; Iba-1 ionized calcium binding adaptor molecule-1; TGF transforming growth factor; GATA-3 GATA transcription factor 3; IFN $\gamma$ interferon- $\gamma$; T-bet T-box transcription factor TBX21; Th T helper; CNS central nervous system; OVA ovalbumin; BALB/c mice albino, immunodeficient laboratory-bred strain of the house mouse; NK natural killer; ICAM-1 intercellular adhesion molecule 1; BALF bronchoalveolar lavage fluid; CCL11 C-C Motif Chemokine Ligand 11.

Javed et al. [52] highlighted a modulation of microglial activation by $\beta$-caryophyllene in a rotenone (ROT)-induced animal model of Parkinson's disease. Indeed, while rotenone injections induced a significant loss of dopaminergic neurons in substantia nigra, as a result of glial cell activation, administration of $\beta$-caryophyllene $(50 \mathrm{mg} / \mathrm{kg}$ i.p.) decreased the microglia activity, attenuated oxidative/nitrosative stress and neuroinflammation, and inhibited gliosis and pro-inflammatory cytokine release; these effects have been associated with the down-expression of Iba- 1 antibody, upregulated in activated macrophages and responsible for oxidative injury.

Similarly, Askari et al. [44] found that the protective effects of low-dose $\beta$-caryophyllene $(5 \mathrm{mg} / \mathrm{kg}$ ) in an experimental autoimmune encephalomyelitis (EAE) mouse model of chronic multiple sclerosis was associated with a modulation of microglia and systemic lymphocyte immunity. Indeed, the treatment induced a decrease in the microglia activation as well as in the levels of TNF $\alpha$, PGE2, iNOS, and NO/urea pro-inflammatory factors and an increase in anti-inflammatory cytokines, such as interleukin IL-10 [44]. Along with microglia, $\beta$-caryophyllene induced a marked lowering of the leucocyte population in the spinal cord and a decrease in the CD4+ and CD8+ T lymphocytes in the peripheral lymphoid tissues and in the axonal demyelination by modulating the $\mathrm{T}$ helper-1/T regulatory cell (Th1/Treg) immune balance [45].

\subsection{Effects of Caryophyllane Sesquiterpenes on Other Monocytic Cells}

Monocytes are both circulating and tissue-resident blood cells, which take part in the "mononuclear phagocyte system", along with macrophages and dendritic cells, but differ due to their rapid recruitment towards inflamed sites [34]. Circulating and tissueresident monocytes are also known as "Ly6Clow "and "Ly6Chigh" cells [29]. The first ones are patrolling monocytes and play a key role in the maintenance of endothelial integrity by removing damaged cells and debris from the vasculature, leading to a resolution of the 
inflammation in the damaged tissues [54]. Moreover, they interact with metastatic tumor cells and counteract their viability by recruiting and activating natural killer (NK) cells [34]. By contrast, Ly6 $\mathrm{C}^{\text {high }}$ monocytes express chemokine receptor 2 (CCR2), whose activation by CC-chemokine ligand 2 (CCL2) leads to their rapid mobilization [27]. Once recruited in the peripheral tissues, the Ly $6 \mathrm{C}^{\text {high }}$ monocytes can not only act as precursors of tissue-resident macrophages but can also differentiate into functionally distinct monocyte-derived cells, acquiring inflammatory effector functions and regulatory properties in order to promote tissue repair $[27,29,34]$. The plastic capacity of monocytes is helpful in the restoration of tissue integrity and function by favouring the process of cell debris, the degradation of the extracellular matrix, cytokine catabolism, the release of regulatory mediators (such as the IL-10, anti-inflammatory cytokine that can counteract the activity of resident microglia), the suppression of resident activated macrophages, and the clearance of neutrophils from the damaged tissue [34].

Gertsch and colleagues investigated the ability of $\beta$-caryophyllene to counteract the LPS-induced activation of the mitogen-activated protein kinase 12 (p38), extracellular signal-regulated kinase 2 (Erk1/2), and Jun Nuclear Kinase $\frac{1}{2}$ (JNK) pathways in primary CD14+ monocytes. In particular, a $1 \mathrm{~h}$ pre-treatment with $0.5 \mu \mathrm{M} \beta$-caryophyllene before LPS stimulation significantly decreased the activation of the Erk1/2, JNK1/2, and MAPK signaling, thus lowering the levels of proinflammatory IL- $1 \beta$ and TNF- $\alpha$ cytokines; conversely, LPS-induced p38 activation was not significantly affected by $\beta$-caryophyllene [43].

$\beta$-Caryophyllene has been also studied for its ability to modulate monocyte function in endothelial disfunction and inflammation [36]. Monocytes are known to be involved in the generation of atherosclerotic plaques and endothelial dysfunction as a consequence of their accumulation in growing lesions, lipid uptake, and enhanced expression of proinflammatory cytokines, such as IL-6, IL-1 and TNF- $\alpha$, vascular cell adhesion molecule1 (VCAM-1), and monocyte chemoattractant protein 1 (MCP-1), that lead to a further recruitment of monocytes and to inflammation development [34].

Zhang et al. [36] found that $\beta$-caryophyllene was able to attenuate the TNF- $\alpha$-induced attachment of THP-1 monocytes on HUVEC cells and to lower the expression of VCAM-1 and Interferon Regulatory Transcription Factor 1 (IRF-1), probably as a consequence of JAK2/STAT1 pathway inhibition and a CB2 receptor modulation. In addition, the decreased expression of IRF-1 can be responsible for the lowered recruitment of monocytes and macrophages and for the decreased expression of iNOS, which can contribute to the anti-inflammatory effects of $\beta$-caryophyllene. A down regulation of VCAM- 1 expression by $\beta$-caryophyllene was also confirmed in a mouse model of LPS-induced aortic inflammation [36].

\subsection{Modulation of Lymphocyte Function}

Lymphocytes are white blood cells grouped in B cells, T cells, and natural killer (NK) cells [55]; B cells are involved in humoral immunity and counteract pathogens through the release of antibodies and also promote clearance of cellular debris; T cells are involved in immune memory, host defence, and inflammatory response, thanks to their differentiation in cell subtypes, including memory and effector T cells [55]. Effector T cells are distinguished in CD8+ T cells, characterized by antigen-specific cytotoxicity and TNF- $\alpha$ and IFN- $\gamma$ production, and in CD4+ T cells, which are further subdivided into helper $\mathrm{T}$ cells, such as the Th1, Th17, and Th2 subsets [55]. The Th1 subset activates macrophages, produces IFN- $\gamma$, and is responsible for pathogen clearance; moreover, it plays a crucial role in autoimmune diseases and in chronic inflammatory disorders, along with the Th17 subset, which is responsible for the recruitment of neutrophils [56]. By contrast, Th2 cells release anti-inflammatory cytokines, such as IL-4, stimulate B cell proliferation and are involved in allergic response. CD4+ T cells can be also differentiated in T-regulatory cells (Tregs), which have regulatory properties to avoid autoimmunity response [55]. Different studies highlighted a possible modulation by caryophyllane sesquiterpenes of lymphocyte function; in particular, Di Sotto and colleagues [46,47] showed that both $\beta$-caryophyllene 
and $\beta$-caryophyllene oxide were nonmutagenic in human isolated primary lymphocytes, thus suggesting their safe use. Moreover, $\beta$-caryophyllene $(0.5-100 \mu \mathrm{M})$ resulted in being able to protect lymphocytes from the clastogenic damage of ethyl methane sulfonate, likely acting through desmutagenic mechanisms [46].

Askari et al. [44] studied the ability of $\beta$-caryophyllene to modulate the balance of Th1 and Th2 cells in an in vitro model of multiple sclerosis. To this end, spleen lymphocytes isolated from experimental autoimmune encephalomyelitis (EAE) mice, a murine multiple sclerosis model, were exposed to myelin oligodendrocyte glycoprotein $\left(\mathrm{MOG}_{35-55}\right)$ and $\beta$-caryophyllene 0.2 and $1 \mu \mathrm{M}$. Treatment with $\beta$-caryophyllene affected cell proliferation and decreased the $\mathrm{MOG}_{35}$-55-induced expression of the pro-inflammatory cytokines IFN- $\gamma$ and IL-17 (produced by Th1 and Th17, respectively), while enhancing the release of the antiinflammatory IL-4 and IL-10 (produced by Th2); as a result, the ratios between IFN- $\gamma /$ IL-4 and IL-17/IL-10 were decreased [44]. These results suggested that $\beta$-caryophyllene can protect against multiple sclerosis by attenuating lymphocyte autoreactivity and limiting the inflammatory response through stimulating the activation of Th2 anti-inflammatory cells.

Similarly, a $1 \mathrm{~h}$ exposure to $\beta$-caryophyllene $1-100 \mu \mathrm{M}$ enhanced the IL-10 levels and decreased the release of IFN- $\gamma$, without affecting IL-4 levels, in $\mathrm{MOG}_{35}-55$-treated T-lymphocytes isolated from EAE mice; this effect was found to be associated with the activation of CB2 receptors, as confirmed by the disappeared effects in the presence of the selective AM630 CB2 antagonist [45]. Indeed, the activation of CB2 receptors has been reported to inhibit lymphocyte $T$ migration, to modulate the immune system, and to counteract the inflammatory response [45]. These protective effects seem to be related to the activation of the PI3K/Akt signaling pathway [44], as displayed by Yamaguchi et al. for $\beta$-caryophyllene [30].

As mentioned above, Th2 cells also play a central role in allergic disease and airway hyperreactivity; indeed, they promote eosinophils recruitment, mast cell growth, mucus hypersecretion, and IgE synthesis through the release of cytokines such as IL-4, IL-5, IL9, and IL-13 [56]. Therefore, their modulation can be approached as a possible strategy against allergy and asthma. In line with this evidence, the ability of $\beta$-caryophyllene and $\alpha$-humulene ( 1 and $10 \mu \mathrm{M})$ to counteract the ovalbumin-induced airway inflammation, in a mediastinal lymph node cell culture, has been studied [48]. Despite a null activity of $\beta$-caryophyllene, $\alpha$-humulene was able to reduce IL- 5 levels and Th2 cytokine release, thus suggesting a possible interest in this sesquiterpene as an attractive molecule for the treatment of asthma and related inflammatory and allergic diseases [48].

$\beta$-Caryophyllene has also shown to be able to modulate natural killer (NK) cell function in an Ehrlich ascites tumor-bearing mouse model [57]. These cells act as natural sentinels and are widespread in lymphoid and nonlymphoid tissues, where they represent a minor fraction of the total lymphocytes [58]. They can discriminate target cells from other "self-cells " through cell surface activating and inhibitory receptors, among which are human ULBP and MIC molecules and TLR ligands [59]. The capability of NK cells to act in the immune system response depends on the cytokine microenvironment and on interactions with other cells, such as T cells, dendritic cells (DCs), and macrophages [60]. Da Silva et al. [57] found that treatment of Ehrlich ascites tumor-bearing mice with $20 \mathrm{mg} / \mathrm{kg}$ $\beta$-caryophyllene significantly increased levels of splenic NK cells and improved their cytotoxicity against YAC-1, a Moloney virus-induced mouse T-cell lymphoma of A/SN origin, and Ehrlich ascites cells, despite a lower effect of $\alpha$-humulene. Considering that during the Ehrlich ascites tumor growth, the level of NK cell activity in spleen cells has been found to be decreased, the results obtained by Da Silva et al. [57] suggest that the anti-tumor effect of $\beta$-caryophyllene in the Ehrlich ascites tumor is mediated by an increase in NK cell activity.

\subsection{Effects of Caryophyllane Sesquiterpenes on Neutrophiles and Eosinophils}

Neutrophiles are the first line of innate immune defense against infectious diseases and are deemed to be potent inflammatory mediators, causing inflammatory tissue damage [61] Moreover, neutrophils provide signals to other innate immune cells (NK cells and dendritic 
cells) in response to invading foreign danger [62]. In acute infections, they are charged with cytotoxic granules, containing antimicrobial molecules (such as proteases, lactoferrin, and myeloperoxidase), and possess a strong capability for exocytosis during the infection or inflammatory process [63]. Interaction of neutrophils with dendritic cells (DCs) induces production of interleukin-12 (IL-12) by DCs and helps in their maturation and in the activation of T cells [64]. Infiltration of neutrophiles is an also important process in hepatic diseases; indeed, recent evidence has revealed a strong circulating flux in chronically ethanol-fed mice, such as alcoholic hepatitis $(\mathrm{AH})$, characterized by acute neutrophilic infiltration associated with chronic liver failure and high mortality [65].

Varga et al. [51] evaluated the possible protective role of $\beta$-caryophyllene in a steatohepatitis mouse model, induced by a liquid diet containing $5 \%$ ethanol for 10 days. Administration of $\beta$-caryophyllene ( $10 \mathrm{mg} / \mathrm{kg}$ i.p.) produced hepatoprotective effects and lowered the neutrophil inflammatory infiltrates associated with a lowering in the expression of the vascular adhesion molecules of ICAM-1, E-selectin, and P-selectin and in the inflammatory cytokines CXCL1/KC and TNF $\alpha$. Medeiros et al. [53] also showed that both $\beta$-caryophyllene and $\alpha$-humulene ( $50 \mathrm{mg} / \mathrm{kg}$ per os) reduced neutrophile recruitment and migration in rat models of LPS-induced acute inflammation. A modulation of eosinophil infiltration in bronchoalveolar lavage fluid (BALF) from BALB/c mice model carrying ovalbumin-induced airway allergic inflammation by $\alpha$-humulene $(50 \mathrm{mg} / \mathrm{kg})$ was found too [48].

\section{Discussion}

The present systematic review highlights that caryophyllane sesquiterpenes possess immunomodulatory properties which can contribute to their beneficial effects in various pathological conditions. Among the caryophyllane sesquiterpenes, $\beta$-caryophyllene is the most studied compound in both in vitro and in vivo models; the modulation of macrophage function in inflammatory conditions has been mainly characterized, although the changes in the recruitment of other immune cells, including lymphocytes, neutrophiles, and eosinophiles in other pathologies, such as tumors and allergic diseases, have been highlighted too. Similar effects on macrophage function have been found for $\beta$-caryophyllene oxide, albeit highlighted in just one study [33]. Considering the structural similarity with $\beta$-caryophyllene and the recently highlighted ability to modulate CB2 receptor expression [2], it is conceivable that it can act like the lead compound, thus suggesting the need for further investigation.

As regards $\alpha$-humulene, though it is poorly studied, the available evidence highlighted its ability to counteract the LPS-induced inflammatory response of macrophages in vitro at high concentration [32], suggesting a weaker potency compared to $\beta$-caryophyllene and $\beta$-caryophyllene oxide. Conversely, it was able to modulate immune response related to allergic diseases (e.g., decreased immune cell infiltration, inhibition of the Nf-kB and AP-1 pathways, and the release of asthma-related modulators, such as CCL11, LTB4 and IL-5) in mice, as displayed in Figure 3, despite a null effect of $\beta$-caryophyllene [48]. This evidence suggests a possible role of $\alpha$-humulene as a novel strategy to treat asthma and allergic diseases and deserves to be further investigated.

The in vitro immunomodulatory effects of $\beta$-caryophyllene were usually studied in the concentration range of $0.25-50 \mu \mathrm{M}$, while at higher concentrations the substance seemed to affect cell viability, which was probably due to a stimulation of the pro-apoptotic pathways [30]. Interestingly, $\beta$-caryophyllene exhibited cytoprotective and anti-inflammatory properties against different stressors, including LPS and A $\beta_{1-42}$ peptide, and in different in vitro models of macrophages, microglial cells, monocytes, and lymphocytes, likely ascribed to the activation of $\mathrm{CB} 2$ receptors. In particular, blocking the microglia activation into the M1 inflammatory phenotype has been associated with the neuroprotective effects of $\beta$-caryophyllene, which have been further confirmed in animal models of Parkinson's disease and multiple sclerosis. 


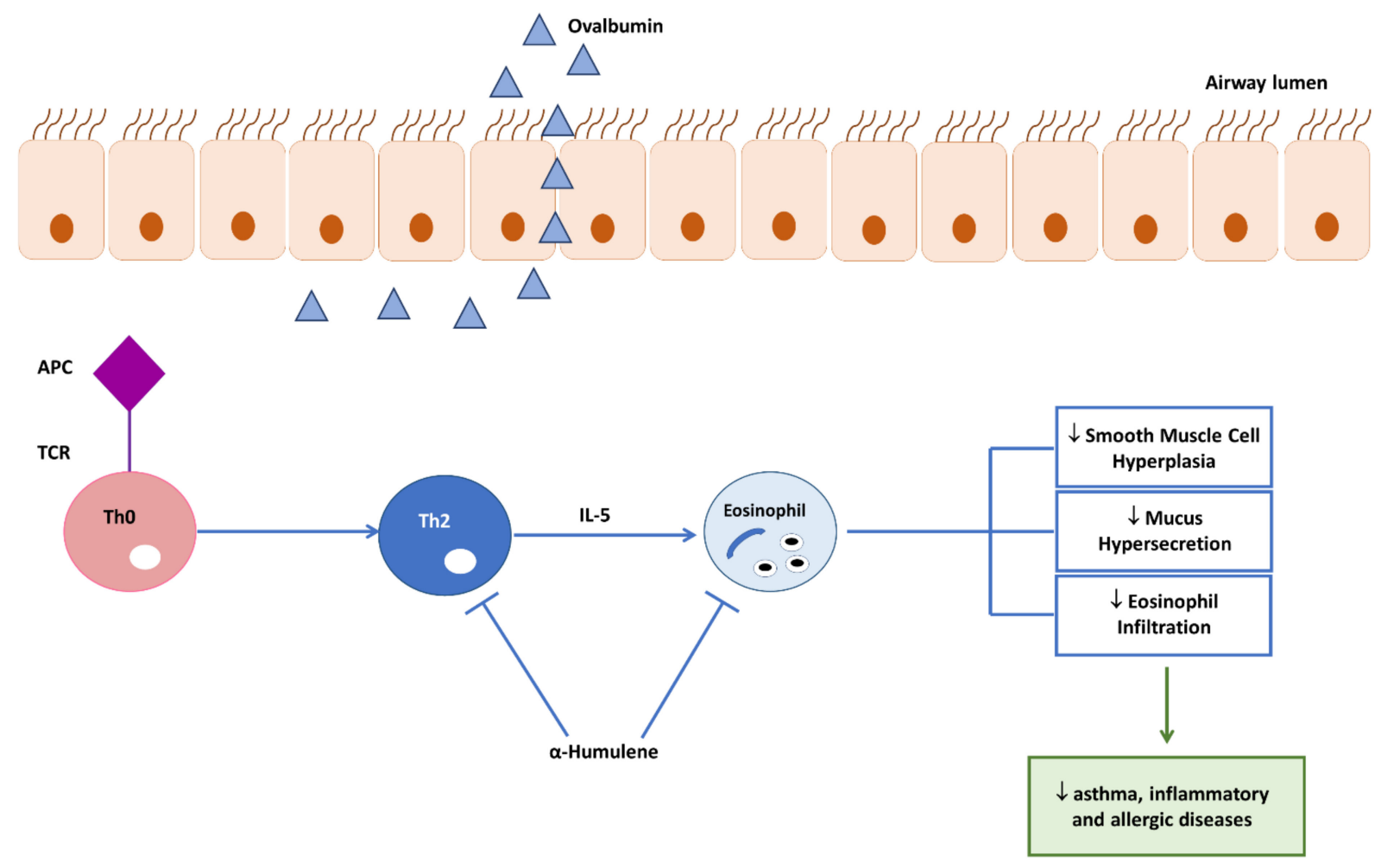

Figure 3. Proposed mechanisms accounting for the modulation of immune response related to allergic diseases by $\alpha$-humulene. The substance was found to be able to block the Th2-mediated activation of eosinophils, thus reducing the inflammatory response. $\downarrow$ reduction.

Askari et al. [40] hypothesized that the cytoprotective effects of $\beta$-caryophyllene in microglial cells occurred via activation of the CB2 and PPAR $\gamma$ receptors and through the involvement of ceramides. Indeed, after activation of the CB2 receptor by the sesquiterpene, the CB2-activated $\beta \gamma$-subunit can stimulate sphingomyelinase (SMase) activity, responsible for producing ceramides, which in turn activate the PPAR- $\gamma$ receptor [49], leading to anti-inflammatory and antioxidant effects [40]. As a consequence, PPAR $\gamma$ can control the inflammatory response through the inhibition of Nf-kB and other inflammatory pathways and the activation of antioxidant defences, such as Nrf2/HO-1 signaling [40]. Accordingly, decreased levels of pro-inflammatory factors, such as TNF- $\alpha$, IL-1 $\beta$, IL-10, NO and PGE2, and oxidative stress parameters (e.g., ROS level reduction), along with an inhibition of iNOS and COX-2 enzymes and a restoring of antioxidant defenses (i.e., GSH) has been found in microglial cells after treatment with $\beta$-caryophyllene $[40,42,44,45]$. The proposed mechanism underlying the immune-mediated neuroprotective effects of $\beta$-caryophyllene is summarized in Figure 4.

$\beta$-Caryophyllene was also found to be able to modulate lymphocyte function in a mouse model of multiple sclerosis, promoting the anti-inflammatory Th2 response and attenuating Th1 activity [44,45]. Similarly, a switch to the anti-inflammatory macrophage phenotype, along with a reduced infiltration of leukocytes (i.e., macrophages and neutrophiles) by the sesquiterpene has been highlighted in animal models of alcoholic steatohepatitis, colitis, atherosclerosis, and nephropathy [36-38,51]. The immunomodulatory properties of $\beta$-caryophyllene have been also highlighted in cancer diseases, in which the substance reduced macrophage recruitment and tumor growth [35] and restored natural killer cell activity in a mouse model of Ehrlich ascites [57]. The chemopreventive effects of $\beta$-caryophyllene against environmental pollutants, which can lead to immune cell degeneration, have been also highlighted in lymphocytes [46]. This evidence strengthens the previously highlighted interest in these compounds as possible adjuvant treatments in cancer chemotherapy and as cancer immunomodulators [7]; moreover, immunomodulation 
can be deemed as novel possible chemopreventive mechanisms of caryophyllane sesquiterpene to be further investigated. However, more studies clarifying the complex mechanisms involved, among which is the modulation of different targets in the endocannabinoidome, are expected and essential to address further the therapeutical applications of these substances. Along with the interest in the immunomodulant properties of caryophyllane sesquiterpenes and the multiple and pleiotropic mechanisms involved, the present systematic review highlights some issues to be considered for improving the available knowledge and their possible developments. A major issue is the purity of the caryophyllane sesquiterpenes used in the reviewed studies; according to the selection criteria, some records have been excluded as the purity of the tested substances was not specified or was poor (i.e., lower than 90\%); sometimes, essential oils containing $80 \% \beta$-caryophyllene along with $20 \%$ other compounds have been used instead of the pure compound.

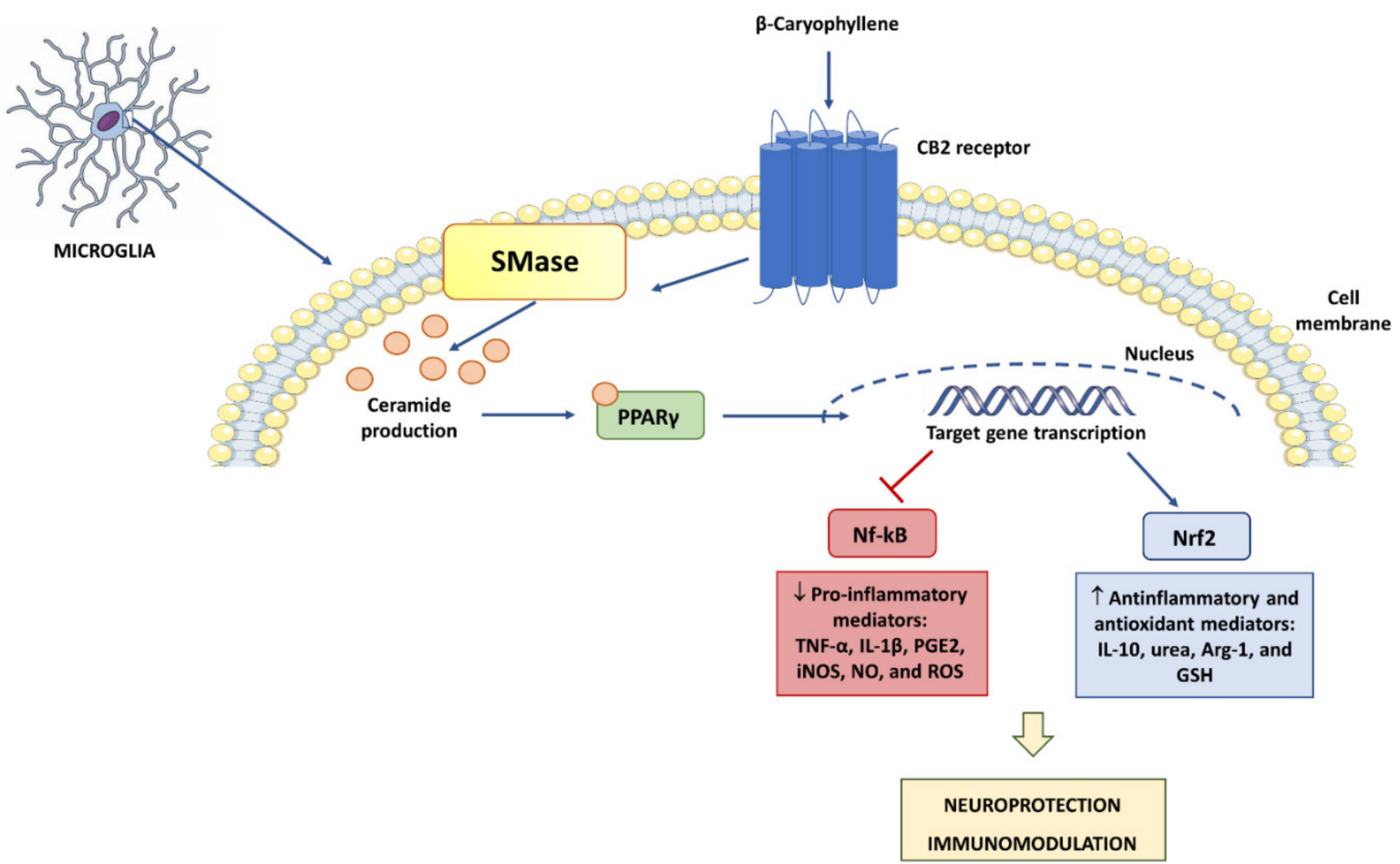

Figure 4. Proposed mechanism underlying the immune-mediated neuroprotective effects of $\beta$ caryophyllene via activation of CB2 and PPAR $\gamma$ receptors through the involvement of ceramides. $\uparrow$ increase; $\downarrow$ reduction.

This is a critical methodologic feature as high impurity levels can dramatically affect the activity of the tested compounds, leading to unreliable results. Indeed, in our previous study, we highlighted that very low concentrations of caryophyllane sesquiterpenes were able to synergize cannabidiol cytotoxicity [2]; therefore, considering the possible modulating effects of minor compounds, the true mechanism of the tested substance is not ensured. As suggested by the best practices to be applied in phytopharmacological research, details about compound purity should be reported; in particular, the use of high purity (95-99\%) compounds is recommended [66]. Moreover, the selected studies are mostly focused on macrophages modulation by caryophyllane sesquiterpenes, while otherwise the effect on immune function is measured as a secondary effect. More specific and high-quality studies, which evaluate the effect of these sesquiterpenes on multiple immune system processes and in specific diseases, such as tumor, metabolic, and allergic-related inflammation, along with neuroinflammation are required. Promising preclinical results, based on high-quality studies and standardized methodologies, can support a further pharmaceutical interest, leading to clinical evaluation and practical application. To this end, pharmacokinetic and bioavailability evaluation should be performed, due to the limited solubility of these sub- 
stances in aqueous fluids, which can lead to inconstant biological responses. Moreover, in the development of suitable pharmaceutical formulations, such as liposomes, inclusion complexes, or oil/water microemulsions [67-69], overcoming this limit remains a major challenge in the achievement of a pharmaceutical development of these compounds.

\section{Conclusions}

Caryophyllane sesquiterpenes are unique natural compounds widely occurring in nature, especially in plant essential oils, that have attracted a great attention over the years due to their multiple and pleiotropic bioactivities. The present systematic review highlights the ability of these substances, especially $\beta$-caryophyllene and $\alpha$-humulene, to modulate immune function, and this effect seems to be positively involved in the beneficial properties of these substances, especially in neuroprotection, inflammatory-based disease, cancer, and allergies.

Despite lacking clinical evidence, the available studies suggest a further interest in these properties, which can be approached not only as novel strategies for the treatment of immune-based diseases but also as adjuvant treatments in support of standard pharmacotherapies. The present overview encourages further high-quality studies to better characterize these properties and to support a further pharmaceutical development.

Author Contributions: Conceptualization, A.D.S. and S.D.G.; data curation, M.G., E.P. and A.D.S.; formal analysis, M.G., E.P. and A.D.S.; funding acquisition, A.D.S.; investigation, M.G., E.P., S.D.G. and A.D.S.; methodology, A.D.S.; project administration, A.D.S.; resources, M.G., E.P., S.D.G. and A.D.S.; software, M.G., E.P., S.D.G. and A.D.S.; supervision, A.D.S. and S.D.G.; visualization, A.D.S. and S.D.G.; writing—original draft, M.G., E.P., S.D.G. and A.D.S.; writing—review and editing, A.D.S. and S.D.G. All authors have read and agreed to the published version of the manuscript.

Funding: This research received no external funding.

Informed Consent Statement: Not applicable.

Data Availability Statement: Not applicable.

Acknowledgments: The Authors thank "Enrico and Enrica Sovena" Foundation (Italy) for supporting the Authors by fellowships.

Conflicts of Interest: The authors declare no conflict of interest.

\section{References}

1. Di Sotto, A.; Mancinelli, R.; Gullì, M.; Eufemi, M.; Mammola, C.L.; Mazzanti, G.; Di Giacomo, S. Chemopreventive potential of caryophyllane sesquiterpenes: An overview of preliminary evidence. Cancers 2020, 12, 3034. [CrossRef] [PubMed]

2. Di Giacomo, S.; Mariano, A.; Gullì, M.; Fraschetti, C.; Vitalone, A.; Filippi, A.; Mannina, L.; Scotto d'Abusco, A.; Di Sotto, A. Role of caryophyllane sesquiterpenes in the entourage Effect of Felina 32 Hemp inflorescence Phytocomplex in triple negative MDA-MB-468 breast cancer cells. Molecules 2021, 26, 6688. [CrossRef]

3. Garzoli, S.; Pirolli, A.; Vavala, E.; Di Sotto, A.; Sartorelli, G.; Božović, M.; Angiolella, L.; Mazzanti, G.; Pepi, F.; Ragno, R. Multidisciplinary approach to determine the optimal time and period for extracting the essential oil from Mentha suaveolens Ehrh. Molecules 2015, 20, 9640-9655. [CrossRef] [PubMed]

4. Schepetkin, I.A.; Özek, G.; Özek, T.; Kirpotina, L.N.; Khlebnikov, A.I.; Quinn, M.T. Chemical composition and immunomodulatory activity of Hypericum perforatum essential oils. Biomolecules 2020, 10, 916. [CrossRef] [PubMed]

5. Ingallina, C.; Sobolev, A.P.; Circi, S.; Spano, M.; Fraschetti, C.; Filippi, A.; Di Sotto, A.; Di Giacomo, S.; Mazzoccanti, G.; Gasparrini, F.; et al. Cannabis sativa L. Inflorescences from Monoecious Cultivars Grown in Central Italy: An Untargeted Chemical Characterization from Early Flowering to Ripening. Molecules 2020, 25, 1908. [CrossRef]

6. Mariano, A.; Di Sotto, A.; Leopizzi, M.; Garzoli, S.; Di Maio, V.; Gullì, M.; Dalla Vedova, P.; Ammendola, S.; Scotto d'Abusco, A. Antiarthritic effects of a root extract from Harpagophytum procumbens DC: Novel insights into the molecular mechanisms and possible bioactive phytochemicals. Nutrients 2020, 12, 2545. [CrossRef]

7. Di Sotto, A.; Vitalone, A.; Di Giacomo, S. Plant-Derived Nutraceuticals and Immune System Modulation: An Evidence-Based Overview. Vaccines 2020, 8, 468. [CrossRef]

8. Bain, B.J. Structure and function of red and white blood cells and platelets. Medicine 2021, 49, 183-188. [CrossRef]

9. Kumar, D.; Romero, Y.; Schuck, K.N.; Smalley, H.; Subedi, B.; Fleming, S.D. Drivers and regulators of humoral innate immune responses to infection and cancer. Mol. Immunol. 2020, 121, 99-110. [CrossRef] [PubMed] 
10. Day, C.L.; Kaufmann, D.E.; Kiepiela, P.; Brown, J.A.; Moodley, E.S.; Reddy, S.; Mackey, E.W.; Miller, J.D.; Leslie, A.J.; DePierres, C.; et al. PD-1 expression on HIV-specific T cells is associated with T-cell exhaustion and disease progression. Nature 2006, 443, 350-354. [CrossRef] [PubMed]

11. Finlay, C.M.; Walsh, K.P.; Mills, K.H. Induction of regulatory cells by helminth parasites: Exploitation for the treatment of inflammatory diseases. Immunol. Rev. 2014, 259, 206-230. [CrossRef] [PubMed]

12. Yanaba, K.; Bouaziz, J.D.; Matsushita, T.; Magro, C.M.; St Clair, E.W.; Tedder, T.F. B-lymphocyte contributions to human autoimmune disease. Immunol. Rev. 2008, 223, 284-299. [CrossRef]

13. Havnaer, A.; Han, G. Autoinflammatory disorders: A review and update on pathogenesis and treatment. Am. J. Clin. Dermatol. 2019, 20, 539-564. [CrossRef] [PubMed]

14. Stegenga, M.E.; van der Crabben, S.N.; Blümer, R.M.E.; Levi, M.; Meijers, J.C.; Serlie, M.J.; Tanck, M.W.; Sauerwein, H.P.; van der Poll, T. Hyperglycemia enhances coagulation and reduces neutrophil degranulation, whereas hyperinsulinemia inhibits fibrinolysis during human endotoxemia. Blood 2008, 112, 82-89. [CrossRef] [PubMed]

15. Chao, W.C.; Yen, C.L.; Wu, Y.H.; Chen, S.Y.; Hsieh, C.Y.; Chang, T.C.; Ou, H.Y.; Shieh, C.C. Increased resistin may suppress reactive oxygen species production and inflammasome activation in type 2 diabetic patients with pulmonary tuberculosis infection. Microbes Infect. 2015, 17, 195-204. [CrossRef] [PubMed]

16. Joshi, M.B.; Lad, A.; Prasad, A.S.B.; Balakrishnan, A.; Ramachandra, L.; Satyamoorthy, K. High glucose modulates IL-6 mediated immune homeostasis through impeding neutrophil extracellular trap formation. FEBS Lett. 2013, 587, 2241-2246. [CrossRef]

17. Berbudi, A.; Surendar, J.; Ajendra, J.; Gondorf, F.; Schmidt, D.; Neumann, A.L.; Wardani, A.P.; Layland, L.E.; Hoffmann, L.S.; Pfeifer, A.; et al. Filarial infection or antigen administration improves glucose tolerance in diet-induced obese mice. J. Innate Immun. 2016, 8, 601-616. [CrossRef] [PubMed]

18. Chawla, A.; Nguyen, K.D.; Goh, Y.P.S. Macrophage-mediated inflammation in metabolic disease. Nat. Rev. Immunol. 2011, 11, 738-749. [CrossRef]

19. Restrepo, B.I.; Twahirwa, M.; Rahbar, M.H.; Schlesinger, L.S. Phagocytosis via complement or Fc-gamma receptors is compromised in monocytes from type 2 diabetes patients with chronic hyperglycemia. PLoS ONE 2014, 9, e92977. [CrossRef]

20. Ramirez, K.; Fornaguera-Trias, J.; Sheridan, J.F. Stress-induced microglia activation and monocyte trafficking to the brain underlie the development of anxiety and depression. Curr. Top. Behav. Neurosci. 2017, 31, 155-172. [PubMed]

21. Tay, T.L.; Savage, J.C.; Hui, C.W.; Bisht, K.; Tremblay, M.E. Microglia across the lifespan: From origin to function in brain development, plasticity and cognition. J. Physiol. 2017, 595, 1929-1945. [CrossRef] [PubMed]

22. Lin, Y.C.; Chang, L.Y.; Huang, C.T.; Peng, H.M.; Dutta, A.; Chen, T.C.; Yeh, C.T.; Lin, C.Y. Effector/memory but not naive regulatory $\mathrm{T}$ cells are responsible for the loss of concomitant tumor immunity. J. Immunol. 2009, 182, 6095-6104. [CrossRef]

23. Galluzzi, L.; Chan, T.A.; Kroemer, G.; Wolchok, J.D.; López-Soto, A. The hallmarks of successful anticancer immunotherapy. Sci. Transl. Med. 2018, 10, eaat7807. [CrossRef]

24. Taefehshokr, S.; Parhizkar, A.; Hayati, S.; Mousapour, M.; Mahmoudpour, A.; Eleid, L.; Rahmanpour, D.; Fattahi, S.; Shabani, H.; Taefehshokr, N. Cancer immunotherapy: Challenges and limitations. Pathol. Res. Pract. 2021, 229, 153723. [CrossRef] [PubMed]

25. Welch, V.; Petticrew, M.; Petkovic, J.; Moher, D.; Waters, E.; White, H.; Tugwell, P. Extending the PRISMA statement to equityfocused systematic reviews (PRISMA-E 2012): Explanation and elaboration. Int. J. Equity Health 2015, 14, 92. [CrossRef] [PubMed]

26. Chen, O.; Donnelly, C.R.; Ji, R.R. Regulation of pain by neuro-immune interactions between macrophages and nociceptor sensory neurons. Curr. Opin. Neurobiol. 2020, 62, 17-25. [CrossRef]

27. Murray, P.J.; Wynn, T.A. Protective and pathogenic functions of macrophage subsets. Nat. Rev. Immunol. 2011, 11, 723-737. [CrossRef]

28. Domoto, R.; Sekiguchi, F.; Tsubota, M.; Kawabata, A. Macrophage as a peripheral pain regulator. Cells 2021, 10, 1881. [CrossRef]

29. Li, C.; Xu, M.M.; Wang, K.; Adler, A.J.; Vella, A.T.; Zhou, B. Macrophage polarization and meta- inflammation. Transl. Res. 2018, 191, 29-44. [CrossRef]

30. Yamaguchi, M.; Levy, R.M. Metaxalone suppresses production of inflammatory cytokines associated with painful conditions in mouse macrophages RAW264.7 cells in Vitro: Synergistic effect with $\beta$-caryophyllene. Curr. Mol. Med. 2020, 20, 643-652. [CrossRef]

31. Yamaguchi, M.; Levy, R.M. The combination of catechin, baicalin and $\beta$-caryophyllene potentially suppresses the production of inflammatory cytokines in mouse macrophages in vitro. Exp. Ther. Med. 2019, 17, 4312-4318. [CrossRef]

32. Da Silva, S.M.M.; Costa, C.R.R.; Gelfuso, G.M.; Guerra, E.N.S.; de Medeiros Nóbrega, Y.K.; Gomes, S.M.; Pic-Taylor, A.; FonsecaBazzo, Y.M.; Silveira, D.; Magalhães, P.O. Wound healing effect of essential oil extracted from Eugenia dysenterica DC (Myrtaceae) Leaves. Molecules 2018, 24, 2. [CrossRef] [PubMed]

33. Ku, C.M.; Lin, J.Y. Anti-inflammatory effects of 27 selected terpenoid compounds tested through modulating Th1/Th2 cytokine secretion profiles using murine primary splenocytes. Food Chem. 2013, 141, 1104-1113. [CrossRef]

34. Guilliams, M.; Mildner, A.; Yona, S. Developmental and functional heterogeneity of monocytes. Immunity 2018, 49, 595-613. [CrossRef] [PubMed]

35. Jung, J.I.; Kim, E.J.; Kwon, G.T.; Jung, Y.J.; Park, T.; Kim, Y.; Park, J.H.Y. $\beta$-Caryophyllene potently inhibits solid tumor growth and lymph node metastasis of B16F10 melanoma cells in high-fat diet-induced obese C57BL/6N mice. Carcinogenesis 2015, 36, 1028-1039. [CrossRef] [PubMed] 
36. Zhang, Z.; Yang, C.; Dai, X.; Ao, Y.; Li, Y. Inhibitory effect of trans-caryophyllene (TC) on leukocyte- endothelial attachment. Toxicol. Appl. Pharmacol. 2017, 329, 326-333. [CrossRef] [PubMed]

37. Horváth, B.; Mukhopadhyay, P.; Kechrid, M.; Patel, V.; Tanchian, G.; Wink, D.A.; Pacher, P. $\beta$-Caryophyllene ameliorates cisplatin-induced nephrotoxicity in a cannabinoid 2 receptor-dependent manner. Free Radic. Biol. Med. 2012, 52, $1325-1333$. [CrossRef] [PubMed]

38. Bento, A.F.; Marcon, R.; Dutra, R.C.; Claudino, R.F.; Cola, M.; Leite, D.F.P.; Calixto, J.B. $\beta$ - Caryophyllene inhibits dextran sulfate sodium-induced colitis in mice through CB2 receptor activation and PPAR $\gamma$ pathway. Am. J. Clin. Pathol. 2011, 178, 1153-1166. [CrossRef]

39. Ojha, S.; Javed, H.; Azimullah, S.; Haque, M.E. $\beta$-Caryophyllene, a phytocannabinoid attenuates oxidative stress, neuroinflammation, glial activation, and salvages dopaminergic neurons in a rat model of Parkinson disease. Mol. Cell. Biochem. 2016, 418, 59-70. [CrossRef] [PubMed]

40. Askari, V.R.; Shafiee-Nick, R. The protective effects of $\beta$-caryophyllene on LPS-induced primary microglia M1/M2 imbalance: Mechanistic evaluation. Life Sci. 2019, 219, 40-73. [CrossRef] [PubMed]

41. Tian, X.; Liu, H.; Xiang, F.; Xu, L.; Dong, Z. $\beta$-Caryophyllene protects against ischemic stroke by promoting polarization of microglia toward M2 phenotype via the TLR4 pathway. Life Sci. 2019, 237, 116915. [CrossRef] [PubMed]

42. Hu, Y.; Zeng, Z.; Wang, B.; Guo, S. Trans-caryophyllene inhibits amyloid $\beta$ (A $\beta$ ) oligomer-induced neuroinflammation in BV-2 microglial cells. Int. Immunopharmacol. 2017, 51, 91-98. [CrossRef] [PubMed]

43. Gertsch, J.; Leonti, M.; Raduner, S.; Racz, I.; Chen, J.Z.; Xie, X.Q.; Zimmer, A. Beta-caryophyllene is a dietary cannabinoid. Proc. Natl. Acad. Sci. USA 2008, 105, 9099-9104. [CrossRef] [PubMed]

44. Askari, V.R.; Rahimi, V.B.; Tabatabaee, S.A.; Shafiee-Nick, R. Combination of Imipramine, a sphingomyelinase inhibitor, and $\beta$-caryophyllene improve their therapeutic effects on experimental autoimmune encephalomyelitis (EAE). Int. Immunopharmacol. 2019, 77, 105923. [CrossRef] [PubMed]

45. Alberti, T.B.; Barbosa, W.L.R.; Vieira, J.L.F.; Raposo, N.R.B.; Dutra, R.C. (-)- $\beta$-Caryophyllene, a CB2 receptor-selective phytocannabinoid, suppresses motor paralysis and neuroinflammation in a murine model of multiple sclerosis. Int. J. Mol. Sci. 2017, 18, 691. [CrossRef] [PubMed]

46. Di Sotto, A.; Mazzanti, G.; Carbone, F.; Hrelia, P.; Maffei, F. Inhibition by $\beta$-caryophyllene of ethyl methanesulfonate-induced clastogenicity in cultured human lymphocytes. Mutat. Res. Genet. Toxicol. Environ. Mutagen. 2010, 699, 23-28. [CrossRef] [PubMed]

47. Di Sotto, A.; Maffei, F.; Hrelia, P.; Castelli, F.; Sarpietro, M.G.; Mazzanti, G. Genotoxicity assessment of $\beta$-caryophyllene oxide. Regul. Toxicol. Pharmacol. 2013, 66, 264-268. [CrossRef] [PubMed]

48. Rogerio, A.P.; Andrade, E.L.; Leite, D.F.; Figueiredo, C.P.; Calixto, J.B. Preventive and therapeutic anti-inflammatory properties of the sesquiterpene $\alpha$-humulene in experimental airways allergic inflammation. Br. J. Pharmacol. 2009, 158, 1074-1087. [CrossRef]

49. Hait, N.C.; Maiti, A. The role of sphingosine-1-phosphate and ceramide-1-phosphate in inflammation and cancer. Mediat. Inflamm. 2017, 2017, 4806541. [CrossRef] [PubMed]

50. Dhopeshwarkar, A.; Mackie, K. CB2 Cannabinoid receptors as a therapeutic target-what does the future hold? Mol. Pharmacol. 2014, 86, 430-437. [CrossRef] [PubMed]

51. Varga, Z.V.; Matyas, C.; Erdelyi, K.; Cinar, R.; Nieri, D.; Chicca, A.; Pacher, P. $\beta$-Caryophyllene protects against alcoholic steatohepatitis by attenuating inflammation and metabolic dysregulation in mice. Br. J. Pharmacol. 2018, 175, 320-334. [CrossRef] [PubMed]

52. Javed, H.; Azimullah, S.; Haque, M.E.; Ojha, S.K. Cannabinoid type 2 (CB2) receptors activation protects against oxidative stress and neuroinflammation associated dopaminergic neurodegeneration in rotenone model of Parkinson's disease. Front. Neurosci. 2016, 10, 321. [CrossRef] [PubMed]

53. Medeiros, R.; Passos, G.F.; Vitor, C.E.; Koepp, J.; Mazzuco, T.L.; Pianowski, L.F.; Calixto, J.B. Effect of two active compounds obtained from the essential oil of Cordia verbenacea on the acute inflammatory responses elicited by LPS in the rat paw. Br. J. Pharmacol. 2007, 151, 618-627. [CrossRef] [PubMed]

54. Thomas, G.; Tacke, R.; Hedrick, C.C.; Hanna, R.N. Nonclassical patrolling monocyte function in the vasculature. Arterioscler. Thromb. Vasc. Biol. 2015, 35, 1306-1316. [CrossRef]

55. Larosa, D.F.; Orange, J.S. 1. Lymphocytes. J. Allergy Clin. Immunol. 2008, 121, S364-S412. [CrossRef]

56. Cosmi, L.; Maggi, L.; Santarlasci, V.; Liotta, F.; Annunziato, F. T helper cells plasticity in inflammation. Cytom. A 2014, 85, 36-42. [CrossRef]

57. Da Silva, S.L.; Figueiredo, P.M.; Yano, T. Chemotherapeutic potential of the volatile oils from Zanthoxylum rhoifolium Lam leaves. Eur. J. Pharmacol. 2007, 576, 180-188. [CrossRef]

58. Vivier, E.; Tomasello, E.; Baratin, M.; Walzer, T.; Ugolini, S. Functions of natural killer cells. Nat. Immunol. 2008, 9, 503-510. [CrossRef]

59. Hart, O.M.; Athie-Morales, V.; O'Connor, G.M.; Gardiner, C.M. TLR7/8-mediated activation of human NK cells results in accessory cell-dependent IFN- $\gamma$ production. J. Immunol. 2005, 175, 1636-1642. [CrossRef]

60. Long, E.O. Ready for prime time: NK cell priming by dendritic cells. Immunity 2007, 26, 385-387. [CrossRef]

61. Gordon, S. Elie Metchnikoff: Father of natural immunity. Eur. J. Immunol. 2008, 38, 3257-3264. [CrossRef] 
62. Kaufmann, S.H. Immunology's foundation: The 100-year anniversary of the Nobel Prize to Paul Ehrlich and Elie Metchnikoff. Nat. Immunol. 2008, 9, 705-712. [CrossRef] [PubMed]

63. Borregaard, N.; Sørensen, O.E.; Theilgaard-Mönch, K. Neutrophil granules: A library of innate immunity proteins. Trends Immunol. 2007, 28, 340-345. [CrossRef] [PubMed]

64. Megiovanni, A.M.; Sanchez, F.; Robledo-Sarmiento, M.; Morel, C.; Gluckman, J.C.; Boudaly, S. Polymorphonuclear neutrophils deliver activation signals and antigenic molecules to dendritic cells: A new link between leukocytes upstream of T lymphocytes. J. Leukoc. Biol. 2006, 79, 977-988. [CrossRef] [PubMed]

65. Gao, B.; Ahmad, M.F.; Nagy, L.E.; Tsukamoto, H. Inflammatory pathways in alcoholic steatohepatitis. J. Hepatol. 2019, 70, $249-259$. [CrossRef] [PubMed]

66. Izzo, A.A.; Teixeira, M.; Alexander, S.P.; Cirino, G.; Docherty, J.R.; George, C.H.; Insel, P.A.; Ji, Y.; Kendall, D.A.; Panattieri, R.A. A practical guide for transparent reporting of research on natural products in British Journal of Pharmacology: Reproducibility of natural product research. Br. J. Pharmacol. 2020, 177, 2169-2178. [CrossRef] [PubMed]

67. Di Sotto, A.; Paolicelli, P.; Nardoni, M.; Abete, L.; Božović, M.; Di Giacomo, S.; Mazzanti, G.; Casadei, M.A.; Petralito, S. SPC Liposomes as possible delivery systems for improving bioavailability of the natural sesquiterpene $\beta$-caryophyllene: Lamellarity and drug-loading as key features for a rational drug delivery design. Pharmaceutics 2018, 10, 274. [CrossRef] [PubMed]

68. Lou, J.; Teng, Z.; Zhang, L.; Yang, J.; Ma, L.; Wang, F.; Tian, X.; An, R.; Yang, M.; Zhang, Q. $\beta$-caryophyllene/hydroxypropyl- $\beta$ cyclodextrin inclusion complex improves cognitive deficits in rats with vascular dementia through the cannabinoid receptor type 2 -mediated pathway. Front. Pharmacol. 2017, 8, 2. [CrossRef] [PubMed]

69. Neves, J.K.D.O.; Apolinário, A.C.; Saraiva, K.L.A.; Da Silva, D.T.C.; Reis, M.Y.D.F.A.; Damasceno, B.P.G.L.; Pessoa, A., Jr;; Galvão, M.A.M.; Soares, L.A.L.; Júnior, V.F.D.V. Microemulsions containing Copaifera multijuga Hayne oil-resin: Challenges to achieve an efficient system for $\beta$-caryophyllene delivery. Ind. Crops Prod. 2018, 111, 185-192. [CrossRef] 